\title{
Effect of the Rise in Online Motorcycle Taxi Services on the Number of Motorcycles using the Interrupted Time Series Method
}

\author{
Laras, Y.F. ${ }^{*}$, Rizki, M. ${ }^{2}$, and Joewono, T.B. ${ }^{1}$
}

\begin{abstract}
The substantial growth of motorcycle users in Indonesia is hypothesized to be influenced by a government policy on motorcycle purchase waivers and the massive growth of online motorcycle taxis. This study aims to analyse the relationship between the emergence of online motorcycle taxis and government policy changes towards the number of motorcycles and compare the estimation model seen from the consumer and sales sides. The data were collected from the Indonesian Bureau of Statistics, Motorcycle Industry Association, and World Bank. Several estimation models were built using the interrupted time series method. The results showed that changes in government policy and income per capita significantly increased the number of motorcycles. However, the emergence of online motorcycle taxis negatively affected the increasing number of motorcycles. The results also showed that models with data representing motorcycle usage behavior provided better results than the model with motorcycle sales.
\end{abstract}

Keywords: Number of motorcycles; government policy; online motorcycle taxis; interrupted time series method.

\section{Introduction}

In Indonesia, motorcycles are one of the most popular vehicles with the public. Motorcycles have advantages, such as high mobility and affordable prices [1]. Motorcycles with a relatively small size can be used on narrow roads and facilitate outreach to remote areas. Along with economic development and population growth, the number of cars and motorcycles in developing countries has increased rapidly [2]. Prior studies have found that personal specific variables (i.e., age, income, and occupation) influence motorcycle ownership, and in emerging countries, the motorcycle is associated with income and population [3]. Previous studies showed the significant influence of income on private vehicle ownership [4,5].

Moreover, for the past decades, the government has relaxed the sale of motorcycles. The policy issued by the Financial Services Authority (Otoritas Jasa Keuangan) and Bank of Indonesia indicates that motorcycle sales can proceed with a down payment of $30 \%$, thereby increasing the attractiveness of purchases and affordability for the lower middle class [6].

\footnotetext{
${ }^{1}$ Department of Civil Engineering, Parahyangan Catholic University, Bandung 40117, INDONESIA

${ }^{2}$ Department of Civil Engineering, Institut Teknologi Nasional Bandung, Bandung 40124, INDONESIA

*Corresponding Author, Email: yovita.laras@gmail.com
}

Note: Discussion is expected before November, $1^{\text {st }} 2021$, and will be published in the "Civil Engineering Dimension", volume 24, number 1, March 2022.

Received 29 July 2021; revised 22 September 2021; accepted 29 September 2021.
After the government policy was enacted, motorcycle production in Indonesia increased rapidly due to the demand of five million to six million units per year [7]. This increase is quite significant compared to production before 2005 since there was an increase of two million to three million units per year. In 2015, online motorcycle taxis emerged and significantly grew year by year.

Online transportation or ride-sourcing has become a major innovation in the last decade in the transportation sector [8]. Online transportation uses online platforms, information technology, and smartphones to directly connect available drivers with potential passengers to be efficient, convenient, fast, and transparent [9]. Due to ease and convenience, the popularity of online transportation in Indonesia is increasing. This online transportation service also appears amid the poorly organized public transportation system in Indonesia [10,11]. The number of online transport users has increased and is leading to a growing demand for drivers. The digitalization era has enabled online motorcycle transportation to be more developed than that for cars, with the number of online motorcycle taxi drivers amounting to more than four million throughout Indonesia. From the perspective of users, the services are faster in heavy traffic conditions and cheaper than public transport [12]. In addition, from the perspective of drivers, the recruitment is easy and there is a competitive wage due to the substantial demand. A prior report shows that online motorcycle taxis have provided jobs for drivers [13].

Previous studies on online transportation or online motorcycle taxis have been widely conducted in 
Indonesia. However, most of these studies focused on evaluating user behavior, such as an assessment of the quality of online motorcycle taxi services [14], studies related to the characteristics [15], travel characteristics using online transportation [16], or the substitution effect of ride-sourcing [12,17]. Meanwhile, the study of how online motorcycle taxis have contributed to the total number of motorcycles in Indonesia is still limited.

The study of the role of online motorcycle taxis to the number of motorcycles is important in Indonesia. Firstly, the demand for online motorcycle taxis was predicted to increase steadily in the coming years. If the contribution of online motorcycle taxi services to the number of motorcycles is positive, then the number of motorcycle users will significantly increase in the coming years. Therefore, increases in congestion due to an increase in motorcycle use, traffic accidents and air pollution are inevitable. Secondly, the government is attempting to decrease private vehicle use by implementing public transport and other transport demand management (TDM) policies. However, these investments and intervention will be in vain if the number of motorcycles continues to increase.

Therefore, this study investigates the growth in the number of motorcycles due to the emergence of online motorcycle taxis and government policy changes. The interrupted time series model was used to analyse the relationship. For this purpose, this study collected data regarding motorcycle ownership published by the Indonesian Bureau of Statistics (IBS)/Badan Pusat Statistik [7] and motorcycle sales reported by the Motorcycle Industry Association (MIA)/Asosiasi Industri Sepeda Motor Indonesia [18]. Moreover, to make the exploration of the relationship more comprehensive, the analysis also integrated the effect of the gross domestic product (GDP) and the effect of the government intervention that relaxed the sales of motorcycles in 2015.

\section{Literature Review}

\section{Motorcycles in Indonesia}

Indonesia has experienced substantial growth in the number of motorcycle users over the past several decades. Motorcycles with a relatively small size can be used on narrow roads to facilitate outreach to remote areas. The number of motorcycles in Indonesia ranks first among all types of private vehicles. In 2000, the number of motorcycles reached 13.5 million with a total number of motor vehicles of 18.9 million [7]. In 2018, the number of motorcycles increased to 120.1 million for a total number of motor vehicles of 146.8 million. In other words, the number of motorcycles in Indonesia amounts to $81.78 \%$ of the total number of motor vehicles.
Studies conducted by Wang et al. [5] and Chamon et al. [4] showed that income is one factor that determines private vehicle ownership. According to Nishitateno and Burke [3], the number of motorcycles in developing countries is influenced by two main factors, namely, income and population. Income per capita is the average income of the population in a given country [19]. The income per capita can be obtained by two variables: gross domestic product and population. The gross domestic product (GDP) is one indicator of the economic condition of a country in a given period. Income can determine the ability of people to buy something like a motorcycle. Furthermore, the Indonesian population is influenced by several factors, including birth (the most influential factor), death, and migration [20]. The population can determine the target market for selling motorcycles. As stated by Sitio [21], income and population significantly affect the number of motorcycles in Indonesia. Increases in the population and income increases the number of motorcycles.

\section{Ride-sourcing}

The emergence of online transportation is one example of technological advances. Online transportation services provide vehicles according to the needs of users with a rental system, where users and riders are connected through a smartphone application [16]. The Indonesian public first became acquainted with online transportation services when a U.S.-based company called Uber entered Indonesia in 2014, and this was followed by a Malaysian company called GrabTaxi. Both companies introduced car-based online transportation services. However, there were few indications that online transportation services would become popular in Indonesia.

One of the online transportation services in Indonesia is motorcycle based. People usually use motorcyclebased ride-sourcing for short distances [12]. This service was first introduced in Indonesia by the Gojek company in 2015. Gojek expands its influence by launching an application as a liaison between users and drivers. This application attracts public transportation users because there is no need to move between transportation modes to travel. The certainty of travel costs offered by online transportation attracts the interest of Indonesian people. Many people switch from conventional transportation modes to online transportation modes due to convenience, decreased cost, comfort, and guaranteed security [10]. Currently, online motorcycle taxi service in Indonesia was dominated by two big companies, Gojek and Grab.

According to news published by CNBC [22], by 2020, the number of online motorcycle taxi users in Indonesia reached 21.7 million people who used several applications, such as the Gojek and Grab user 
apps. The Gojek app has been downloaded by more than 155 million users with various services in 167 cities and regencies in Indonesia [23,24]. According to the news published in Bisnis.com [25], the number of online motorcycle taxi drivers throughout Indonesia reached 2.5 million people, and 50\% of the drivers are located in the Greater Jakarta. The number of online motorcycle taxi drivers in each company is uncertain because there is no official tally.

Online motorcycle taxis in Indonesia have caused debate among the public, especially among conventional public transportation business activists. Some people think that the absence of regulations is supporting online transportation companies, such as the absence of tax payments by 'partners' or online motorcycle taxi drivers. Online motorcycle taxis are also considered not to use vehicles to transport passengers by applicable regulations, namely, the rules stipulated in Law No. 22 of 2009 on Traffic and Road Transport. To address the problem, the government issued rules protecting the safety of motorcycle users for the benefit of communities (i.e., online motorcycle taxis and conventional motorcycle taxis). The regulation is stipulated in Regulation of the Minister of Transportation of the Republic of Indonesia Number PM 12 of 2019. Online transportation services have also raised concerns that people will prefer online transportation services over public transportation that has been provided by the government. A study conducted by Irawan et al. [12] in Jakarta, the capital city of Indonesia, shows that online transportation services, especially those based on motorcycles, work as a complement to public transportation services, such as buses and commuter trains. Another study showed that motorcycle-based online transportation services replace public transportation (buses) in Yogyakarta [26]. Moreover, Rizki et al. [27] found that the transition from public transport is more apparent for younger travelers than older ones.

Most of the prior research investigated the impact of online motorcycle taxis from the perspective of users [26-28] and drivers [29]. However, a study at the aggregate level on how the number of online motorcycle taxis influences the total number of motorcycles is still limited. With differences in terms of social, cultural, infrastructure, and economic factors between developed and developing countries, an investigation of this issue in Indonesia is important. The findings from this research are important for understanding potential travel, congestion, and environmental impacts.

\section{Method}

\section{Data Collection}

Analysis for this study employed secondary data drawn from a variety of sources. Data were taken from the IBS, MIA, and the World Bank. The number of motorcycles in Indonesia with IBS data sources was

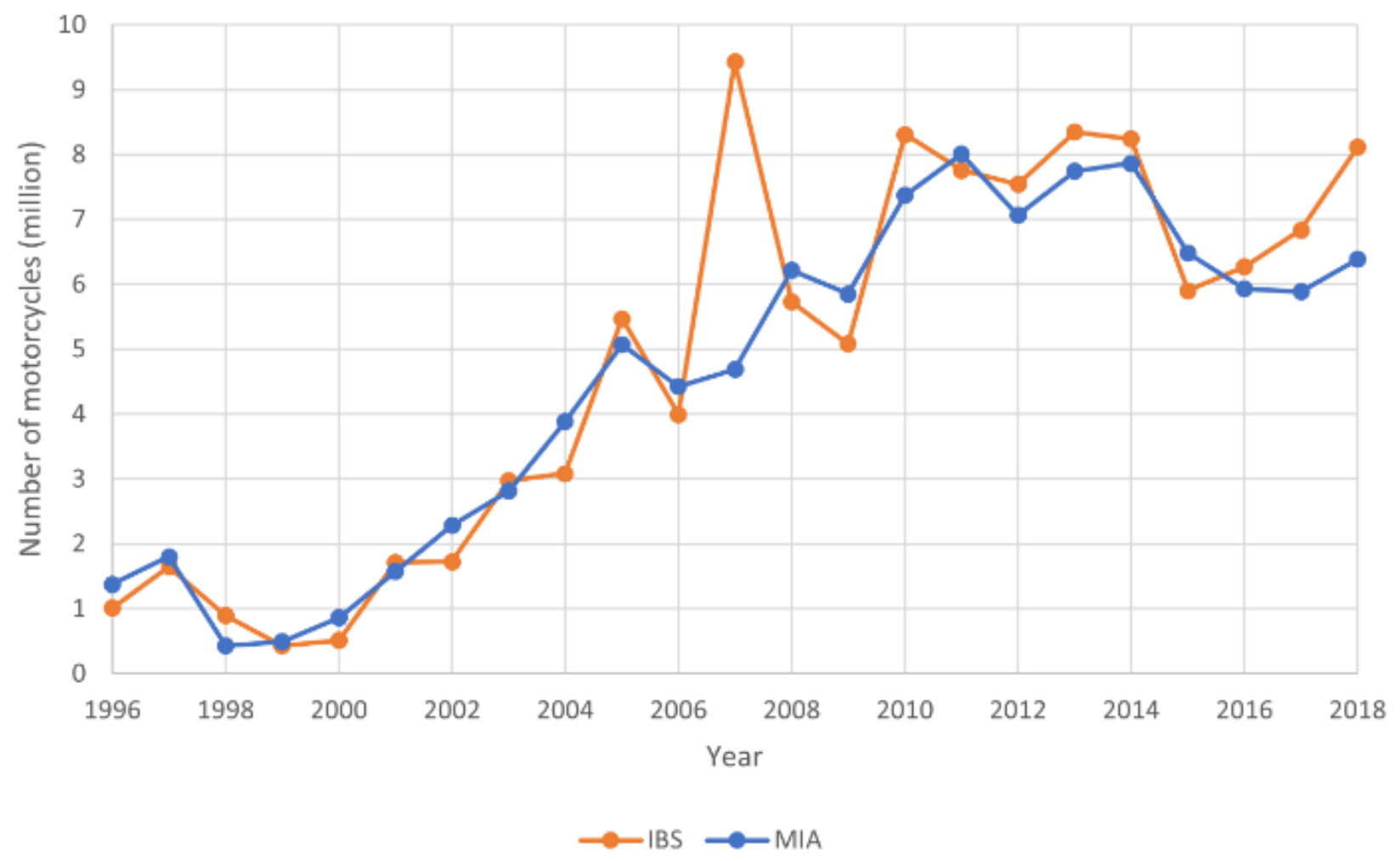

Figure 1. The Increasing (delta) Number of Motorcycles in Indonesia [7,18] 
calculated based on the number of motorcycles registered with the Traffic Corps Indonesian National Police (Korlantas Polri). Korlantas Polri recorded the number of newly registered motorcycles. The number of motorcycle ownership recorded in IBS was based on the number accumulated since the previous year until an increase in the number of motorcycles. Meanwhile, data derived from the MIA was calculated based on the number of motorcycle sales in Indonesia for motorcycles that were produced in Indonesian factories. The number of motorcycle sales has been recorded since 1996; thus, we used data since 1996 for the model estimation. To produce a model that can be compared, the existing IBS data was processed into the increased (delta) number of motorcycles every year. Figure 1 shows the data from two sources.

The Indonesian population was obtained from the World Bank since data was recorded every ten years by the IBS. In addition to the population, the income per capita data for Indonesia was also obtained from the World Bank because the income per capita data was recorded since 2000 by the IBS. The income per capita in Indonesia was not calculated in Rupiah because researchers refer to the currency more commonly used worldwide or the money used as a benchmark for the welfare of the population in a country, namely, the US Dollar (\$).

\section{Interrupted Time Series Method}

The interrupted time series (ITS) method is a method that uses time-series data that incorporates independent variables in the form of intervention variables or dummy variables. These intervention variables interrupt at a point in time. The time-series data was divided into two parts, namely, the period before the intervention and the period after the intervention [30].

This study used two dummy variables. Dummy variables declare qualitatively or categorize variables into quantitative variables. The first dummy variable was a change in government policy regarding the waiver of motorcycle purchases. The policy change occurred in 2005, when the Financial Services Authority of Indonesia (Otoritas Jasa Keuangan) and Bank Indonesia permitted the purchase of motorcycles using a $30 \%$ down payment. According to Setijowarno [6], this policy increases motorcycle sales in Indonesia. The second dummy variable was the appearance of online motorcycle taxis. Online motorcycle taxis appeared in Indonesia in 2015. At that time, there were no online transportation services in Indonesia that used motorcycles as a means of transportation. A dummy variable was expressed in the form of a value of 0 (zero), which stated before the occurrence of changes in government policy or the appearance of online motorcycle taxis, and 1 (one) to declare after the event of changes in government policy or the appearance of online motorcycle taxis.

The ITS analysis method used standard equations, as shown in Equation 1:

$Y_{T}=\beta_{0}+\beta_{1} T+\beta_{2} X_{T}+\beta_{3} T X_{T}+\varepsilon_{i}$

where

$Y_{T} \quad:$ dependent variable,

$X_{T} \quad:$ independent variable,

$T X_{T} \quad$ : dummy variable,

$T \quad$ : time,

$\beta_{0}, \beta_{1}, \beta_{2}, \beta_{3}$ : parameter estimates,

$\varepsilon_{i} \quad:$ residual or error model, and

$i \quad: 1,2,3, \ldots$, n.

The estimation model was built using two types of data with two different sources, namely, data on the number of motorcycles from the IBS to represent the behavior of motorcycle used by consumers and data on the number of motorcycle sales from the MIA to represent motorcycle sales. The two models represent consumer usage behavior (IBS data) (model A) and sales behavior by a single agent brand (MIA data) (model B). Because there is a strong correlation between income and population [8], this study used motorcycles per capita (motorcycle per thousand population) as dependent variables. The per capita income in Indonesia is hypothesized as one of the independent variables that can explain this estimation model. The analysis was performed using RStudio [31].

\section{Model Estimations}

This section presents the results of the estimation model to represent the consumer side model and sales side. The first model (model A) represented consumer behavior in using motorcycles. Model A used data on increasing motorcycles expressed in motorcycles per thousand population as variable dependents. The second model (model B) used information on the number of motorcycle sales stated in motorcycles per thousand population as dependent variables. Both models used the same independent variables, namely, Indonesia GDP per capita, government policy changes in dummy variables, and the emergence of online motorcycle taxis in dummy variables. This study used the period from 1996 to 2018 for analysis.

Table 1 shows the econometric estimation results for both models A and model B. Model A shows goodnessof-fit with an adjusted $\mathrm{R}^{2}$ of 0.82 . Independent variables on model A can describe $82 \%$ of the dependent variable model. At the same time, the adjusted $R^{2}$ obtained for model B is 0.896. In other words, independent variables in model $\mathrm{B}$ can describe $89.6 \%$ 
Table 1. Model Estimations

\begin{tabular}{|c|c|c|c|c|}
\hline \multirow{2}{*}{ Independent Variable } & \multicolumn{2}{|c|}{ Model A } & \multicolumn{2}{|c|}{ Model B } \\
\hline & Coefficient & t-value & Coefficient & t-value \\
\hline Constant & 3.566 & 1.597 & $3.556^{*}$ & 2.486 \\
\hline Government policy [D] & $14.313^{* *}$ & 3.787 & $9.544^{* * *}$ & 3.940 \\
\hline Online motorcycle taxis [D] & $-7.312^{*}$ & -2.165 & $-8.117^{* *}$ & -3.751 \\
\hline GDP per capita & $0.004^{*}$ & 2.459 & $0.005^{* * *}$ & 4.672 \\
\hline $\mathrm{R}^{2}$ & \multicolumn{2}{|c|}{0.845} & \multicolumn{2}{|c|}{0.911} \\
\hline Adj. $R^{2}$ & \multicolumn{2}{|c|}{0.820} & \multicolumn{2}{|c|}{0.896} \\
\hline RMSE & \multicolumn{2}{|c|}{4.515} & \multicolumn{2}{|c|}{2.893} \\
\hline MAE & \multicolumn{2}{|c|}{3.170} & \multicolumn{2}{|c|}{2.234} \\
\hline $\mathrm{AIC}$ & \multicolumn{2}{|c|}{144.614} & \multicolumn{2}{|c|}{124.143} \\
\hline $\mathrm{BIC}$ & \multicolumn{2}{|c|}{150.291} & \multicolumn{2}{|c|}{129.821} \\
\hline $\begin{array}{l}\text { Breusch-Godfrey test for residual auto-correlation } \\
\text { [LM test; df:; p-value] }\end{array}$ & \multicolumn{2}{|c|}{$[1.127 ; 1 ; 0.289]$} & \multicolumn{2}{|c|}{$[6.277 ; 1 ; 0.012]$} \\
\hline $\begin{array}{l}\text { Portmanteau test for white noise of residuals } \\
\text { [X'; df.; } p \text {-value] }\end{array}$ & \multicolumn{2}{|c|}{$[1.183 ; 1 ; 0.277]$} & \multicolumn{2}{|c|}{$[5.998 ; 1 ; 0.014]$} \\
\hline $\begin{array}{l}\text { Bartlett's test for white noise of residuals } \\
\text { [Bartlett's; } p \text {-value] }\end{array}$ & \multicolumn{2}{|c|}{$[0.843 ; 0.477]$} & \multicolumn{2}{|c|}{$[1.376 ; 0.045]$} \\
\hline
\end{tabular}

of the dependent variables in model B. We used the Breusch-Godfrey [32] autocorrelation test to determine the existence of an autocorrelation in the residual estimation models. The results showed that model B had residuals that were correlated with each other. An autocorrelation is not expected in an estimated model. For model A, the residuals did not show autocorrelation. Model A performed better in terms of the Breusch-Godfrey autocorrelation test. The Portmanteau test [33] was used to test the initial hypothesis of a residual estimation model in which the residual underwent a white noise process. The residuals in Model A underwent a white noise process. In contrast, the residuals in model B did not experience white noise. Model A produced an excellent model to use as an estimation model. Like the Breusch-Godfrey test and the Portmanteau test, the Bartlett's test [34] is used to determine the best estimation model by knowing the residual normality of a model. The Bartlett's test showed that model A produced a better model than the $\mathrm{B}$ model. The three residual tests indicated that model $B$ is not a feasible estimation model. The residuals in model $\mathrm{B}$ were autocorrelated, did not experience the white noise process, and were not distributed normally. Model A performed better in all three residual tests, where the model A residuals were not autocorrelated, experienced white noise, and were distributed normally.

Both estimation models show a significant influence by the government policy changes with a coefficient obtained by model A of 14.313 and model B of 9.544 . Changes in government policy increased the number of motorcycles in terms of consumer behavior and sales behavior. The dummy variable that indicates the appearance of online motorcycle taxis was statistically significant and negative. In Table 1 , the coefficients obtained for online motorcycle taxis are - 7.312 for model A and -8.117 for model $\mathrm{B}$. This may mean that since the advent of online motorcycle taxis in Indonesia, the number of motorcycles will increase each year, but the increase is not more than that before the emergence of online motorcycle taxis. This study shows that the income per capita in Indonesia significantly influenced the increasing number of motorcycles. The income per capita in Indonesia can affect the number of motorcycles because it affects the ability of a person to buy an item.

\section{Discussion}

Based on the results of the analysis, it was determined that the government policy had a significant effect on increasing the number of motorcycles in Indonesia. Both models produced consistent findings, namely, that government policy changes in 2005 significantly influenced the number of motorcycles in Indonesia. The change in government made it easier for people to own a motorcycle, especially those in the lower middle class. The ability to buy a motorcycle using a down payment of only $30 \%$ impacted those with a lower financial status. The two models indicated an increase in the number of motorcycles from both sides, namely, from the consumer behavior side and sales behavior side.

The results of both models also confirmed that the Indonesian GDP per capita positively affected the number of motorcycles in Indonesia. This finding is consistent with a study conducted by Sitio [21], which stated that income affects a positive direction in the number of motorcycles in Indonesia. The higher the revenue in a community is, the higher the purchasing power of the community. Therefore, income 
significantly affects the increase in the number of motorcycles, where the higher the income is, the higher the number of motorcycles in Indonesia.

Another finding from the two models is the negative coefficient value for the variable appearance of online motorcycle taxis. It can be interpreted that the emergence of online motorcycle taxis in Indonesia that occurred in 2015 did not increase the number of motorcycles in each thousand population. In other words, the rise in the number of motorcycles since the emergence of online motorcycle taxis was less than the increase before the advent of online motorcycle taxis. The results of this analysis are contrary to a study conducted by Wadud [8], in which the emergence of online motorcycle taxis increased the number of motorcycles in Dhaka, Bangladesh. A possible reason is that the online motorcycle taxis removed the need to own a motorcycle. Within the removal and complementary perspectives [12,28], this finding extends the previous research on how online motorcycles replace private modes. It appeared that the services also influenced the intention of individuals to own a motorcycle. The emergence of online motorcycle taxis provides convenience for people who want high efficiency in terms of energy, time, and cost. Driving a motorcycle requires a set of skills and administrative permissions, whereas using an online motorcycle taxi service does not require special skills. From the perspective of vehicle maintenance and cost of operations, using an online motorcycle taxi eliminates the need to spend money and time each month to care for, pay installments, refuel, and pay for parking. A report by Zaenudin [35] indicated that using an online motorcycle taxi is cheaper than the cost of purchasing, maintaining, refueling, and parking for motorcycles. In the long run, if the quality of online motorcycle taxi services is maintained and the integration to highquality public transport services is increased, the number of motorcycle ownership might decrease while the number of the public transport users might increase. In addition, before partners are registered with online motorcycle taxis, they already have motorcycles for personal use or for conventional motorcycle taxis. This can also cause the emergence of online motorcycle taxis to not contribute to an increase in the number of motorcycles.

The findings herein suggest that the best model that can be used as an estimation model is model A because it had a better goodness-of-fit and good residual test results. The statistical testing of model $\mathrm{A}$ resulted in small and near-zero RMSE, MAE, AIC, and BIC values, so this model is a suitable statistical test model. The model A residual tests resulted in a pvalue greater than $\alpha$. In other words, the residual model A were not autocorrelated, experienced white noise, and had a normal distribution. A good model is a residual model with no autocorrelation that experiences white noise and is normally distributed.
Model A obtained the predicate as a good estimation model in residual testing.

On the other hand, the residual test results for model $\mathrm{B}$ indicated a $\mathrm{p}$-value smaller than $\alpha$. The model B residuals were autocorrelated, did not experience white noise, and were not normally distributed. Residuals with these characteristics are residuals from poor models to use as estimation models. The residual test results of model $B$ make it an estimation model that does not match the observation data with a high error rate, although the goodness-of-fit for model B indicated that model B is a good model.

\section{Conclusion}

Due to the rapid use of online motorcycle taxis and increase in the number of drivers, this research investigated how ride-sharing services influenced the number of motorcycles. By gathering data from Indonesian organizations, this study increased the knowledge of motorcycle ownership in developing countries. The study found that an increase in the number of motorcycles in Indonesia was significantly influenced by changes in government policy. Since the enactment of the government policy stipulated in Bank Indonesia Regulation Number 7 in 2005, the number of motorcycles in every thousand population increased. The results also showed that per capita income significantly influenced the increase in the number of motorcycles. Furthermore, this study found that the emergence of online motorcycle taxis in Indonesia negatively influenced the number of motorcycles. This phenomenon is likely because online $\mathrm{m}$ otorcycle taxis offer passengers convenience, especially in major cities that often experience congestion. Online motorcycle taxis also offer private transport users to avoid vehicle maintenance and administration fees as well as parking fees. Therefore, the services could maximize the benefits for users while decreasing the desire to own a motorcycle.

Along with the findings of this study, there are limitations. In addition to the use of intervention variables in government policy changes and the emergence of online motorcycle taxis, other intervention variables (i.e., daily activity and travel by individuals) need to be investigated in developing countries, such as Indonesia. Further studies that incorporate the dynamic of urban transport policies and economics may contribute to establishing a better model to predict the number of motorcycles in Indonesia.

\section{References}

1. Zukhruf, F., Frazila, R.B., and Wibowo, S.S., Efektivitas Jalur Sepeda Motor Pada Jalan Perkotaan Menggunakan Model Simulasi-Mikro, Jurnal Transportasi, 10(1), 2010, pp. 23-32. 
2. Gómez-Gélvez, J.A. and Ubando, C., Joint Disaggregate Modeling of Car and Motorcycle Ownership: Case study of Bogotá, Colombia, Transportation Research Record, 2451, 2014, pp. 149-156.

3. Nishitateno, S. and Burke, P.J., The Motorcycle Kuznets Curve, 2014/04, 2014.

4. Chamon, M., Mauro, P., and Okawa, Y., Mass Car Ownership in the Emerging Market Giants, Economic Policy, 23(54), 2008, pp. 243-296.

5. Wang, Y., Teter, J., and Sperling, D., China's Soaring Vehicle Population: Even Greater than Forecasted?, Energy Policy, 39(6), 2011, pp. 3296-3306.

6. OtoDetik, Kecelakaan Tak Pernah Turun, Pengamat: Setop Produksi Motor 80 cc ke atas, 2020. https://oto.detik.com/motor/d-4920769/kecelakaan-tak-pernah-turun-pengamat-setop-produksi-motor-80-cc-ke-atas/1 (accessed Aug. 13, 2020).

7. IBS, Perkembangan Jumlah Kendaraan Bermotor menurut Jenis, Indonesian Bureau of Statistics, 2019. https://www.bps.go.id/linkTable Dinamis/view/id/1133 (accessed Aug. 08, 2020).

8. Wadud, Z., The Effects of E-Ridehailing on Motorcycle Ownership in an Emerging-Country Megacity, Transportation Research Part A: Policy and Practice, 137(March), 2020, pp. 301-312.

9. Shaheen, S., Chan, N., Bansal, A., and Cohen, A., Shared Mobility. Definitions, Industry Developments, and Early Understanding, 2015, p. 30.

10. Aziah, A. and Adawia, P.R., Analisis Perkembangan Industri Transportasi Online di Era Inovasi Disruptif (Studi Kasus PT Gojek Indonesia), Cakrawala, 18(2), 2018, pp. 149-156.

11. DetikInet, Awal Mula Transportasi Online Menjamur di Indonesia, Detik inet, 2017. https://inet.detik.com/cyberlife/d-3609781/awalmula-transportasi-online-menjamur-di-indonesia? utm_source=copy_url\&utm_campaign=detikcom socmed\&utm_medium=btn\&utm_content=inet (accessed Aug. 13, 2020).

12. Irawan M.Z., Belgiawan, Tarigan, A.K.M., and Wijanarko, F., To Compete or Not Compete: Exploring the Relationships between MotorcycleBased Ride-Sourcing, Motorcycle Taxis, and Public Transport in The Jakarta Metropolitan Area, Transportation, 47(5), 2020, pp. 2367-2389.

13. Azzuhri, A.A., Syarafina, A., Yoga, F.T., and Amalia, R., A Creative, Innovative, and Solutive Transportation for Indonesia with Its Setbacks and How to Tackle Them: A Case Study of the Phenomenal GOJEK, Review of Integrative Business and Economics Research, 7(1), 2018, pp. 59-67.

14. Mawar, G.P., Otu, M.N., and Suprayatna, N., Analisis Pengaruh Kualitas Layanan dan Harga
Transportasi Online terhadap Kepuasan Mahasiswa Pengguna Ubermotor di Provinsi Banten, 2(3), 2020.

15. Annisa, F.M., Hubungan Preferensi Pengguna terhadap Intensitas Penggunaan Transportasi Online di Kota Bandung, Universitas Katolik Parahyangan, 2019.

16. Riandiatmi, O., Persepsi Masyarakat Kota Bandung dan Kota Bangkok terhadap Transportasi Online, Universitas Katolik Parahyangan, 2019.

17. Rizki, M., Joewono, T.B., and Belgiawan, P.F., Travel Experience and Multitasking of Toll Road Users in Jakarta Metropolitan Area, Indonesia: An Investigation for Passenger of Private Car, Taxi, and Ride-sourcing, Journal of the Eastern Asia Society for Transportation Studies, 13, 2019, pp. 523-541, doi: 10.11175/easts.13.523.

18. MIA, Statistic Distribution, Motorcycle Industry Association, 2020. https://www.aisi.or.id/statistic/ (accessed Nov. 23, 2020).

19. Syah, A., Ekonomi untuk SMA dan MA kelas $X$. ESIS, 2006.

20. Fahrina, A.R., Pengaruh Pendapatan Daerah dan Populasi Penduduk terhadap Kondisi Keuangan Pemerintah Daerah (Studi pada Pemerintah Daerah Provinsi/Kabupaten/Kota di Wilayah Jawa Barat Tahun Anggaran 20162018), 2020.

21. Sitio, B.S., Pengaruh Variabel Ekonomi terhadap Jumlah Sepeda Motor di Indonesia, Universitas Negeri Semarang, 2015.

22. Astutik, Y., 21,7 Juta Masyarakat Indonesia pakai Transportasi Online, CNBC Indonesia, 2020. https://www.cnbcindonesia.com/tech/20200 317150135-37-145529/217-juta-masyarakatindonesia-pakai-transportasi-online (accessed Dec. 20, 2020).

23. Andriani, D., Jumlah Pengguna Aktif Gojek di Indonesia Setara dengan Aplikasi Ride-Sharing Terbesar Dunia, Bisnis.com, 2019. https://ekonomi.bisnis.com/read/20190829/98/1141953/juml ah-pengguna-aktif-gojek-di-indonesia-setaradengan-aplikasi-ride-sharing-terbesar-dunia (accessed Dec. 20, 2020).

24. Gojek, Kini Gojek Hadir di 167 Kota dan Kabupaten Indonesia, 2018. https://www.gojek.com/ blog/gojek/go-jek-dimana-mana/ (accessed Dec. 21, 2020).

25. Azka, R.M., Berapa Sih Jumlah Pengemudi Ojek Online? Simak Penelusuran Bisnis.com!, Bisnis. com, 2019. https://ekonomi.bisnis.com/read/ 20191112/98/1169620/berapa-sih-jumlah-pengemudi-ojek-online-simak-penelusuran-bisnis.com (accessed Dec. 21, 2020).

26. Irawan, M.Z., Belgiawan, P.F., Joewono, T.B., and Simanjuntak, N.I.M., Do Motorcycle-Based Ride-Hailing Apps Threaten Bus Ridership? A Hybrid Choice Modeling Approach with Latent 
Variables, Public Transport, 12(1), 2019, pp. 207231.

27. Rizki, M., Joewono, T.B., Belgiawan, P.F., and Irawan, M.Z., The Travel Behaviour of RideSourcing Users, and Their Perception of the Usefulness of Ride-Sourcing Based On the Users' Previous Modes of Transport: A Case Study in Bandung City, Indonesia, LATSS Research, 2020.

28. Tirachini, A., Ride-Hailing, Travel Behaviour and Sustainable Mobility: an International Review, Transportation, 47(4), 2020, pp. 2011-2047, doi: 10.1007/s11116-019-10070-2.

29. Rizki, M., Joewono, T., Belgiawan, P., and Prasetyanto, D., Exploring the Ride-Hailing Drivers' Characteristics and Their Order Rejection Behavior in Bandung City, In: Mohammed B.S., Shafiq N., Rahman M. Kutty S., Mohamad H., Balogun AL. (eds) ICCOEE 2020. ICCOEE 2021. Lecture Notes in Civil Engineering, vol 132. Springer, Singapore. https://doi.org/10.1007/978-981-33-6311-3_98.
30. Bernal, J.L., Cummins, S., and Gasparrini, A., Interrupted Time Series Regression for the Evaluation of Public Health Interventions: a Tutorial, International Journal of Epidemiology, 46(1), 2017, pp. 348-355.

31. Fox, J. and Weisberg, S., An R Companion to Applied Regression, 3rd ed. SAGE Publications, Inc., 2019.

32. Breusch, T.S., Testing for Autocorrelation in Dynamic Linear Models, Australian Economic Paper, 17(31), 1978, pp. 334-355.

33. Box, G.E.P., Jenkins, G.M., and Reinsel, G.C., Time Series Analysis: Forecasting and Controls, Fourth, Canada: John Wiley \& Sons, Inc, 2008.

34. Bartlett, M.S., On The Theoretical Specification and Sampling Properties of Autocorrelated TimeSeries, Journal of the Royal Statistical Society, 8(1), 1946, pp. 27-41.

35. Zaenudin, A., Motor Pribadi Versus Naik Ojek Online, Mana Lebih Irit?, tirto.id, 2018. https://tirto. id/motor-pribadi-versus-naik-ojek-online-manalebih-irit-cLLz (accessed Jan. 04, 2020). 